\title{
A Chinese Imprint in Insoluble Pollutants Recently Deposited in Central Greenland As Indicated by Lead Isotopes
}

\author{
Aloys J.-M. Bory, ${ }^{\dagger, \perp, *}$ Wafa Abouchami, ${ }^{\ddagger}$ Stephen J. G. Galer, ${ }^{\ddagger}$ Anders Svensson, ${ }^{\S}$ John N. Christensen," \\ and Pierre E. Biscaye ${ }^{\dagger}$ \\ ${ }^{\dagger}$ Lamont-Doherty Earth Observatory of Columbia University, Palisades, New York 10964, United States \\ ${ }^{\ddagger}$ Max Planck Institute for Chemistry, 55128 Mainz, Germany \\ ${ }^{\S}$ Niels Bohr Institute, University of Copenhagen, 2100 Copenhagen, Denmark \\ "Lawrence Berkeley National Laboratory, Berkeley, California 94720, United States
}

\section{Supporting Information}

\begin{abstract}
A unique $\sim 10$ year record of the lead isotopic composition of airborne insoluble particulate matter deposited in central Greenland was extracted from recent snow layers at NorthGRIP $\left(75.1^{\circ} \mathrm{N}, 042.3^{\circ} \mathrm{W}\right.$; elevation $\left.2,959 \mathrm{~m}\right)$, spanning the years 1989-2001. Comparison with lead isotopic signatures of both natural and anthropogenic northern hemisphere $(\mathrm{NH})$ aerosol sources shows that human activities must have accounted for most of the insoluble lead deposited on Greenland during the late 1990s, exceeding by far the natural contribution from large Asian mineral dust inputs. Lead isotopes imply predominance with time of European/Canadian sources over U.S.-derived lead, with an admixed signature typical of Chinese anthropogenic lead sources. The relative contribution of the latter shows a marked seasonal increase during spring. Our record also suggests that China's weight in the overall supply of insoluble pollutants deposited on Greenland was growing over the past decade of the 20th century.
\end{abstract}

\section{INTRODUCTION}

Impurities contained in snow, firn, and ice layers in Greenland provide a record of the history of atmospheric dustiness, ${ }^{1}$ volcanic emissions, ${ }^{2}$ and pollution ${ }^{3}$ in the Northern Hemisphere $(\mathrm{NH})$. The source of the particles deposited onto the ice cap may be investigated using specific intrinsic tracers. Lead isotopes are particularly useful in this respect as they vary widely among both natural and anthropogenic sources of aerosols. ${ }^{4,5}$ Lead isotopes have been used, for instance, to pinpoint mineral dust provenance during the last glacial period ${ }^{6}$ and to recount the history of lead exploitation during Roman times. ${ }^{7}$ More recently, lead isotopes enabled Rosman and coworkers to account for the significant changes in lead concentration in Greenland snows during the period 1960$1988 .^{8}$ In particular, lead isotopes made it possible to establish the switch to unleaded gasoline in the U.S. and the environmental decrease in lead concentration after 1970.

Most of these lead isotope measurements were carried out on bulk snow or ice samples, that is, reflecting the contribution of soluble and insoluble fractions of lead deposits. In the present study, we investigate the lead isotopic composition of insoluble impurities deposited recently in central Greenland, most of which are mineral dust. ${ }^{9}$ Two time-series covering the years 1989-1995 and 1998-2001 were obtained. In addition, a sample collected on Mount Logan - the highest mountain in Canada on the Canadian-Alaskan border-containing particles deposited around 14-18 April $2001^{10}$ during a single, massive Asian dust event, was also analyzed. The main objective of this study was to determine the origin of the insoluble $\mathrm{Pb}$-bearing aerosols reaching the Greenland ice-cap. These lead isotope measurements complement clay mineralogy (X-ray diffraction) and $\mathrm{Sr}-\mathrm{Nd}$ isotope analyses already carried out on these samples. ${ }^{10-12}$ We compare our results with lead isotopic signatures of both natural, ${ }^{6}$ including new data, and anthropogenic $^{13}$ aerosol sources in the northern hemisphere in order to identify the main sources of insoluble lead reaching Greenland during the study period, with implications for recent trans-continental transport and dispersion of natural and anthropogenic aerosols in the $\mathrm{NH}$.

\section{MATERIALS AND METHODS}

Insoluble impurities were extracted by melting and continuousflow centrifugation of large snow samples ( $150 \mathrm{~kg}$ each), excavated horizontally down two snow-pits in the vicinity of the NorthGRIP ice camp $\left(75.1^{\circ} \mathrm{N}, 042.3^{\circ} \mathrm{W}\right.$; elevation $2,959 \mathrm{~m}$; see Supporting Information (SI) Figure S1). The Sharples supercentrifuge we used operated at $\sim 30000 \mathrm{rpm}$, separating

Received: August 10, 2013

Revised: December 20, 2013

Accepted: December 30, 2013

Published: December 30, 2013 


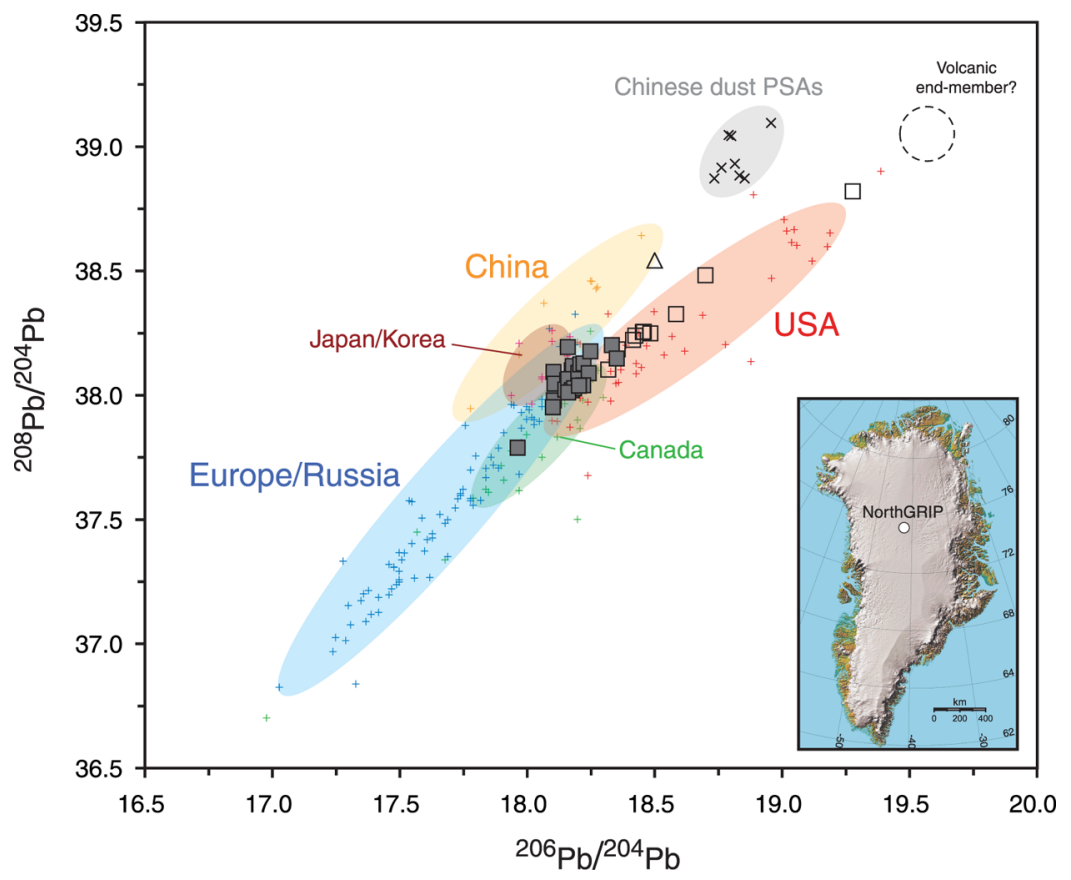

Figure $1 .{ }^{208} \mathrm{~Pb} /{ }^{204} \mathrm{~Pb}$ versus ${ }^{206} \mathrm{~Pb} /{ }^{204} \mathrm{~Pb}$ of insoluble particles extracted from recent snow layers at NorthGRIP, Greenland, deposited during the 1989-95 (open squares) and 1998-2001 (closed squares) time periods (this study). The $\mathrm{Pb}$ isotopic composition of particles deposited at Mount Logan, Canada, around 12-19 April 2001 ${ }^{10}$ during a major Asian dust event (open triangle) is also reported (this study). These results are compared with the $\mathrm{Pb}$ isotopic composition of potential source areas (PSA) of "natural" mineral dust in China (this study and Biscaye et al. ${ }^{6}$ ), and of mid- and high-latitude Northern Hemisphere urban aerosols. ${ }^{4,13,21}$

particles down to $<0.1 \mu \mathrm{m}$ from melted snow, which was discarded, and depositing them on a precleaned PET sheet. The interest of this method is that it enabled us to collect cleanly appropriate amounts of material (several milligrams) in order to carry out mineralogical as well as $\mathrm{Sr}, \mathrm{Nd}$, and $\mathrm{Pb}$ isotopic analyses. For each of the two snow-pits, attempted stratigraphy was obtained from $\delta^{18} \mathrm{O}$ measurements obtained along a vertical profile down the side of the pit. Estimated sampling resolutions range from $\sim 6$ - to $\sim 10$-months for 19891995 time series to $\leq 2$ months for the 1998-2001 times series. The dust-rich snow sample from Mount-Logan was not processed in the field and the particulate matter was recovered later from the snow by evaporation. Field-sampling protocols are fully described elsewhere. ${ }^{10-12}$ All subsequent samplepreparation procedures were completed using precleaned PTFE vessels in clean lab facilities at Lamont-Doherty Earth Observatory of Columbia University (LDEO), New York. Particles were leached with a buffered sodium acetate solution ( $\mathrm{pH} 5$ ) for carbonate removal and rinsed several times with Q$\mathrm{D}$ water. Samples were next digested in a concentrated HF/ $\mathrm{HNO}_{3} / \mathrm{HClO}_{4}(8: 4: 1)$ acid mixture and $\mathrm{Pb}$ was then separated using a 100-200 mesh AG1 X8 anion exchange resin (samples were loaded in $0.7 \mathrm{~N} \mathrm{HBr}$ and $\mathrm{Pb}$ was eluted with $6 \mathrm{~N} \mathrm{HCl}$ ). $\mathrm{Pb}$ isotopes analyses were carried out by thermal ionization mass spectrometry (TIMS) at LDEO (1989-1995 time series), and at the Max Planck Institute for Chemistry (MPI), Mainz (1998-2001 time series and Mount-Logan sample). Pb samples were loaded onto Re filaments along with silicagel$\mathrm{H}_{3} \mathrm{PO}_{4}$ activator. At LDEO, samples were run on a VG Sector 54-30 in static multicollection. Repeated measurements of the NIST SRM-981 Pb standard $(n=9)$ during the period of analyses yielded ${ }^{206} \mathrm{~Pb} /{ }^{204} \mathrm{~Pb},{ }^{207} \mathrm{~Pb} /{ }^{204} \mathrm{~Pb}$ and ${ }^{208} \mathrm{~Pb} /{ }^{204} \mathrm{~Pb}$ of $16.893 \pm 6,15.434 \pm 8$, and $36.512 \pm 23$, respectively. At MPI, measurements were carried using a triple-spike method to correct for instrumental mass bias on a ThermoFinnigan TRITON in static multicollection mode. ${ }^{14}$ Repeated measurements of the NIST SRM-981 Pb standard $(n=16)$ during the period of analyses yielded ${ }^{206} \mathrm{~Pb} /{ }^{204} \mathrm{~Pb},{ }^{207} \mathrm{~Pb} /{ }^{204} \mathrm{~Pb}$ and ${ }^{208} \mathrm{~Pb} /{ }^{204} \mathrm{~Pb}$ of $16.9437 \pm 11,15.5017 \pm 12$, and $36.7319 \pm$ 25 , respectively. The 1989-1995 time series reported data are mass fractionation corrected with propagating error using SRM981 MPI values. Carefully monitored chemistry blanks $(\leq 400$ pg) were always less $0.5 \%$ of $\mathrm{Pb}$ sample weights and were thus considered negligible.

\section{RESULTS AND DISCUSSION}

3.1. Evidence of Significant Anthropogenic Insoluble $\mathrm{Pb}$ Inputs to Greenland. Insoluble lead concentration levels in the snow at NorthGRIP ( $\sim 8$ pg.g ${ }^{-1}$ on average; see SI Table S1) are rather coherent with total lead contents (i.e., combining soluble and insoluble fractions) measured on the Greenland ice-cap at the ACT2 site where $\mathrm{Pb}$ concentration was $19 \mathrm{pg} . \mathrm{g}^{-1}$ in early 1990s snows. ${ }^{3}$ Such a comparison should be made with caution though, considering the lower latitude and altitude of the ACT2 site $\left(66.0^{\circ} \mathrm{N}, 045.2^{\circ} \mathrm{W}\right.$; elevation $\left.2410 \mathrm{~m}\right)$ and associated higher snow accumulation rates (about twice those observed at NorthGRIP). ${ }^{15}$ However, considering that wet deposition processes prevail in Greenland for both soluble and insoluble aerosols, ${ }^{16}$ concentrations are preferred for comparison than fluxes, which may thus be heavily biased by changing accumulation rates. ${ }^{17}$

Lead concentration estimates in the insoluble particles extracted from snow samples at NorthGRIP (up to $>200$ ppm, 95 ppm on average; see SI Table S1), however, greatly exceed the "natural" $\mathrm{Pb}$ content found typically in mineral dust extracted from Greenland glacial ice $(\sim 30 \mathrm{ppm}){ }^{18}$ indicating an extraneous source of $\mathrm{Pb}$. The visual observation of significant blackish soot-like material in all the samples, in 
addition to the major mineral dust fraction, suggested that this "excess" $\mathrm{Pb}$ (which we thus define as the fraction of the insoluble $\mathrm{Pb}$ that is not from mineral dust; see SI Table S1 and Figure S2) might be associated with this dark particulate matter, likely of anthropogenic origin. This is supported by a recent investigation from Hegg et al. ${ }^{19}$ showing that pollution is responsible for most of the light-absorbing aerosols reaching Greenland.

Clay mineralogy and $\mathrm{Sr}$ and $\mathrm{Nd}$ isotopic compositions identify Asian deserts, particularly in northwestern and northern China, as the main sources of mineral dust deposited in central Greenland and at the NorthGRIP site in particular. ${ }^{11,12,20} \mathrm{New} \mathrm{Pb}$ isotope data for these Asian deserts are provided here (details in SI Table S1) along with published numbers, ${ }^{6}$ together with the Greenland snow-pit data in Figure 1. It is clear from such a plot that $\mathrm{Pb}$ isotopic compositions of NorthGRIP insoluble particles are much less radiogenic overall than those of Asian potential mineral dust sources, supporting the view that an additional, unradiogenic and therefore likely anthropogenic $\mathrm{Pb}$-rich end-member is at play. A mixture of dust and combustion products has actually been reported recently for Asian aerosols crossing the North Pacific Ocean, (refs 21,22, and references therein). This is also consistent with the fact that recent atmospheric lead deposits to Devon Island in the Canadian artic have been attributed primarily to industrial emissions. ${ }^{23}$ Contributions to the "excess" $\mathrm{Pb}$ measured in NorthGRIP snows from quiescent degassing of volcanoes ${ }^{24}$ or explosive eruptions, ${ }^{25}$ which display relatively radiogenic signatures, ${ }^{26}$ are, on the other hand, less likely.

Anthropogenic aerosols, however, are generally regarded as being relatively soluble compared to natural aerosols, ${ }^{27}$ as it is also the case for rare-metals-rich aerosols emitted by volcanoes through gas-to-particle conversion. ${ }^{28}$ Our results therefore imply instead that a significant fraction of the combustion (and/or volcanic) products reaching Greenland are not readily soluble.

By comparison, the isotopic composition we measured of the material deposited at Mount Logan -the highest mountain in Canada on the Canadian-Alaskan border- during a single, massive Asian dust event in April $2001^{10}$ has a $\mathrm{Pb}$ isotopic composition lying much closer to the Asian desert crustal isotopic compositions (Figure 1). This is consistent with the fact that this sample was heavily enriched in mineral dust (about 2 orders of magnitude higher) compared to our Greenland samples.

3.2. Mixed Provenance from Various Northern-Hemisphere $\mathrm{Pb}$ Sources. Since the phase-out of leaded gasoline, first in the U.S. in the 1970s and then in most northernhemisphere industrialized nations throughout the following two decades, global lead atmospheric emissions have dropped considerably. ${ }^{13}$ The relative contribution of industrial sources such as coal combustion, smelters and incinerators has therefore become more significant with time, at least on regional scales, ${ }^{4,29,30}$ therefore making it potentially more difficult to use lead isotopes for provenance fingerprinting. Yet, lead isotopic composition of mid- and high-latitude Northern Hemisphere aerosols in urban environments inventoried by Bollhöfer and Rosman ${ }^{4,13}$ still enable the definition of broad "continental" trends in a ${ }^{208} \mathrm{~Pb} /{ }^{204} \mathrm{~Pb}$ vs ${ }^{206} \mathrm{~Pb} /{ }^{204} \mathrm{~Pb}$ plot (Figure 1); similar trends are also observed in ${ }^{208} \mathrm{~Pb} /{ }^{207} \mathrm{~Pb}$ vs ${ }^{206} \mathrm{~Pb} /{ }^{207} \mathrm{~Pb}$ space (not shown). These trends extend from relatively low, unradiogenic European-type $\mathrm{Pb}$ isotope ratios (down to ${ }^{208} \mathrm{~Pb} /{ }^{204} \mathrm{~Pb}=\sim 37$ and ${ }^{206} \mathrm{~Pb} /{ }^{204} \mathrm{~Pb}=\sim 17.25$ ) to high, radiogenic signatures typical of the U.S. end-member $\left({ }^{208} \mathrm{~Pb} /{ }^{204} \mathrm{~Pb}=\sim 38.75\right.$ and $\left.{ }^{206} \mathrm{~Pb} /{ }^{204} \mathrm{~Pb}=\sim 19.5\right)$. The slope of the $\mathrm{Pb}$ isotope array defined by U.S. aerosols is, however, slightly different from that formed by the European aerosols, allowing us to distinguish further between these two sources. The Canadian data, on the other hand, display intermediate values bridging the European and US lead isotopic domains. Among Northern Hemisphere anthropogenic sources of $\mathrm{Pb}$, China stands out as a distinctive end-member, with Chinese aerosols being generally characterized by higher ${ }^{208} \mathrm{~Pb} /{ }^{204} \mathrm{~Pb}$ for a given ${ }^{206} \mathrm{~Pb} /{ }^{204} \mathrm{~Pb}$ ratio (Figure 1 ).

When compared with Northern Hemisphere aerosols, NorthGRIP $\mathrm{Pb}$ isotopic compositions fall at the intersection of the main "anthropogenic" isotopic domains defined in Figure 1. Indeed, NorthGRIP $\mathrm{Pb}$ isotopic compositions lie at the radiogenic ends of the European and Canadian trends, extending in the directions of the more radiogenic US isotopic compositions (mainly 1989-95) and/or toward the Chinese natural (mineral dust) and/or anthropogenic end-members (1998-2001).

Our most radiogenic samples therefore suggest that, despite the phase-out of leaded gasoline in the U.S. by the end of the 1980 s, other U.S. sources contributed to insoluble $\mathrm{Pb}$ deposited in Greenland during the following decade. In particular, three consecutive samples centered around 1993 (one in particular) display a more radiogenic signature compared to the rest of the samples, which could be explained by an unusually high contribution of U.S. $\mathrm{Pb}$ at that time. However, inputs from volcanic exhalations, which are often radiogenic-such as from Iceland ${ }^{31}$-might also be able to explain such signatures. Stratospheric fallouts of aerosols emitted by the Pinatubo eruption in the Philippines in June 1991 cannot be excluded either, as the ensuing global atmospheric impact lasted at least three years. ${ }^{32}$ In fact, it has recently been argued that the Pinatubo eruption could be accountable for the deposit of some unusual siderophile elements that occurred at Summit $\left(72.33^{\circ}\right.$ $\mathrm{N}, 038.75^{\circ} \mathrm{W}$; elevation $3,270 \mathrm{~m}$; see SI Figure S1) during the 1992-1995 period, and most importantly during summer of 1993. ${ }^{33}$ The fact that the 1993 major radiogenic excursion we observe in the lead isotopic composition seem to stretches over the 1992-1994 period would be consistent with the longlasting influence of the Pina Tubo's eruption. A significant contribution from tephra, on the other hand, is not supported by the $\mathrm{Sr}$ and $\mathrm{Nd}$ isotopic compositions of these samples. ${ }^{12}$

However, except for these few exotic samples, the fact that a significant fraction of the $\mathrm{Pb}$ contained in our samples is from mineral dust (estimated to one-third on average) does imply major contributions from less radiogenic anthropogenic sources such as Europe and/or Canada, especially during the most recent part of our record (1998-2001) when the US relative influence appears to have receded. Of all the European sources plotted in Figure 1, Russia, whose lead isotopic signatures $\left({ }^{206} \mathrm{~Pb} /{ }^{204} \mathrm{~Pb}>17.8\right.$ and $\left.{ }^{208} \mathrm{~Pb} /{ }^{204} \mathrm{~Pb}>37.7\right)$ fall at the radiogenic end of the European array as reported by Bollhöfer and Rosman, ${ }^{4,13}$ has (or at least, had in the 1990s), by far the highest $\mathrm{Pb}$ emissions. ${ }^{34}$ One can therefore speculate that Russia likely contributed some $\mathrm{Pb}$ to Greenland over the study decade. This is supported by the fact that Russia was recently reported to provide a significant fraction of the black carbon deposited in Greenland. ${ }^{35}$ In Bollhöfer and Rosman's compilation, a few data from Mongolia and Kazakhstan (not shown), where leaded gasoline was still in use until recently (http://www.unep.org/ PCFV), spread out over the entire European range, suggesting 
that some of the $\mathrm{Pb}$ deposited in Greenland during the period studied might also be derived from these Asian countries. Recent modeling of global dust emission and transport support central Asia as a significant source of aerosols to Greenland. ${ }^{36}$ The paucity of $\mathrm{Pb}$ isotope data from this region is obviously a caveat to $\mathrm{Pb}$ provenance investigations.

Finally, it is clearly apparent that the lead isotopic composition of some NorthGRIP samples -displaying lower ${ }^{206} \mathrm{~Pb} /{ }^{204} \mathrm{~Pb}$ for a given ${ }^{208} \mathrm{~Pb} /{ }^{204} \mathrm{~Pb}$ ratio- is pulled in the direction of the distinct Chinese isotopic domain. This is also noticeable on a ${ }^{206} \mathrm{~Pb} /{ }^{207} \mathrm{~Pb}$ vs ${ }^{208} \mathrm{~Pb} /{ }^{207} \mathrm{~Pb}$ space (see SI Figure $\mathrm{S} 3$ ). Although it is not possible to exclude a possible influence from Japanese and Korean sources as well (Figure 1), the observed shift in the isotopic signature of these samples likely implies an increased relative contribution from Chinese aerosols, considering the overwhelming weight of China in Eastern Asian anthropogenic emissions. ${ }^{37}$

3.3. Chinese Contribution to the Insoluble Lead Pollution Reaching Greenland. Considering that, on a ${ }^{208} \mathrm{~Pb} /{ }^{204} \mathrm{~Pb}$ vs ${ }^{206} \mathrm{~Pb} /{ }^{204} \mathrm{~Pb}$ space, Chinese anthropogenic aerosols align along a distinct trend compared to aerosols derived from other regions of the Northern Hemisphere, one can tentatively quantify the Chinese's relative contribution using the divergence of both the ${ }^{208} \mathrm{~Pb} /{ }^{204} \mathrm{~Pb}$ ratio $\left(\Delta^{208} \mathrm{~Pb}\right)$ and/or the ${ }^{206} \mathrm{~Pb} /{ }^{204} \mathrm{~Pb}\left(\Delta^{206} \mathrm{~Pb}\right)$ from a baseline array (supposedly with no or minimal Chinese influence, which is supported by the fact that the baseline is very close to the regression line calculated for all-but-Chinese Northern Hemisphere (NH) urban aerosols) toward the Chinese isotopic domain (i.e., $\Delta^{208} \mathrm{~Pb}=\left[{ }^{208} \mathrm{~Pb} /{ }^{204} \mathrm{~Pb}_{\text {observed }}-\right.$ $\left.{ }^{208} \mathrm{~Pb} /{ }^{204} \mathrm{~Pb}_{\text {baseline }}\right]_{206}$, where ${ }^{208} \mathrm{~Pb} /{ }^{204} \mathrm{~Pb}_{\text {baseline }}$ is derived from the baseline at the observed ${ }^{206} \mathrm{~Pb} /{ }^{204} \mathrm{~Pb}$; Figure $2 \mathrm{a}$ ). Positive $\Delta^{208} \mathrm{~Pb}$ and $\Delta^{206} \mathrm{~Pb}$ therefore indicate contribution from Chinese sources, the greater the $\Delta$-values the greater the Chinese contribution. A similar approach has been successfully used by Ewing et al. ${ }^{21}$ to discriminate between local and Asian aerosols on the U.S. West coast. One can then estimate the relative weight of the Chinese contribution in percent (expressed as $F_{\text {China }}$ ) by dividing the divergence in ${ }^{208} \mathrm{~Pb} /{ }^{204} \mathrm{~Pb}$ (or ${ }^{206} \mathrm{~Pb} /{ }^{204} \mathrm{~Pb}$ ) by the total difference between the Chinese and the baseline ${ }^{208} \mathrm{~Pb} /{ }^{204} \mathrm{~Pb}\left(\right.$ or ${ }^{206} \mathrm{~Pb} /{ }^{204} \mathrm{~Pb}$; that is, $F_{\text {China }(208 \mathrm{~Pb} / 204 \mathrm{~Pb})}(\%)=\left[{ }^{208} \mathrm{~Pb} /{ }^{204} \mathrm{~Pb}\right.$ observed -

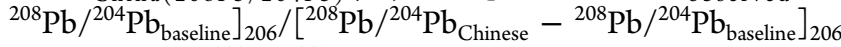
$\times 100$, where ${ }^{208} \mathrm{~Pb} /{ }^{204} \mathrm{~Pb}_{\text {Chinese }}$ is derived from the Chinese regression line at the observed ${ }^{206} \mathrm{~Pb} /{ }^{204} \mathrm{~Pb}$; Figure 2a). Results based on ${ }^{208} \mathrm{~Pb} /{ }^{204} \mathrm{~Pb}$ and ${ }^{206} \mathrm{~Pb} /{ }^{204} \mathrm{~Pb}$ ratios provided similar results and so the averaged values are shown in Figure 3.

According to our calculations, a significant fraction of the insoluble lead deposited in central Greenland derived from China around the beginning of the 2000s (up to $>50 \%$ during the spring of 2001 for instance). Two additional features emerge from these estimates. First, our calculations highlight the peculiar lead isotopic composition of the 1993 level, emphasizing that deposition of some unusual insoluble aerosols, whether anthropogenic (in that case, most likely from the U.S.) or volcanogenic (possibly from Mount Pinatubo eruption; see Section 3.2), occurred around that time. Second, our 1998-2001 time-series, achieved at a much higher temporal resolution, reveals distinct seasonal patterns. In fact, the relative influence of Chinese anthropogenic sources increases sharply during spring of each year compared to the rest of the year (calculations based on the ${ }^{206} \mathrm{~Pb} /{ }^{207} \mathrm{~Pb}$ and
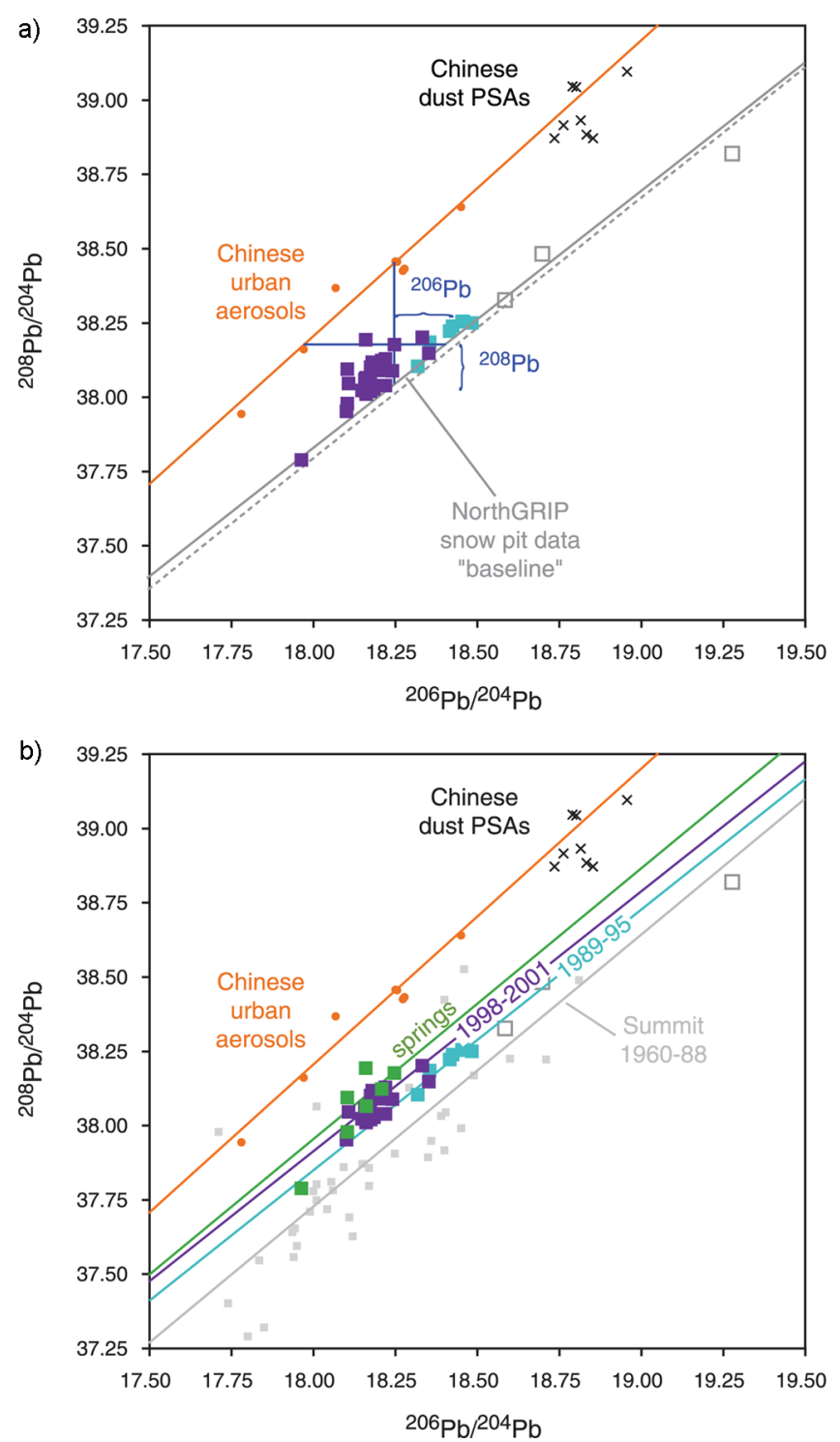

Figure 2. ${ }^{208} \mathrm{~Pb} /{ }^{204} \mathrm{~Pb}$ versus ${ }^{206} \mathrm{~Pb} /{ }^{204} \mathrm{~Pb}$ in NorthGRIP $1989-95$ (blue and open gray squares) and 1998-2001 (purple squares) insoluble particles time series (this study) against lead isotopic composition of aerosols from urban areas in China (regression line also shown $)^{13,21}$ and of Chinese dust PSA samples (this study and Biscaye et al. ${ }^{6}$ ). Experimental error bars (see SI Table S1) are always within data symbols. [a] An example of $\Delta^{206} \mathrm{~Pb}$ and $\Delta^{208} \mathrm{~Pb}$ calculations based on the NorthGRIP sample "baseline" (solid line). The regression line calculated for all Northern Hemisphere $(\mathrm{NH})$ urban aerosols data except those from China is also shown (dotted line). [b] Same data as in Figure 2a. Spring samples (green squares) are distinguished within the NorthGRIP 1998-2001 times series. $\mathrm{Pb}$ isotopic compositions of snows deposited at Summit during the $1960-1988$ period (small light-blue squares) ${ }^{8}$ also shown. Additional linear regressions were calculated for each of the following data sets: Greenland-Summit 1960-1988 bulk snow samples (light-blue line), NorthGRIP 1989-1995 (blue line), 1998-2001 (purple line) and 1998-2001 springs (green line) time series. Note that the three radiogenic values centered around 1993, shown as open gray squares, were not taken into account for the 1989-1995 time series regression line.

${ }^{208} \mathrm{~Pb} /{ }^{207} \mathrm{~Pb}$ as in Ewing et al. ${ }^{21}$ yielded very similar results). This is consistent with observations of Asian aerosol transPacific transport to western North America, which generally 


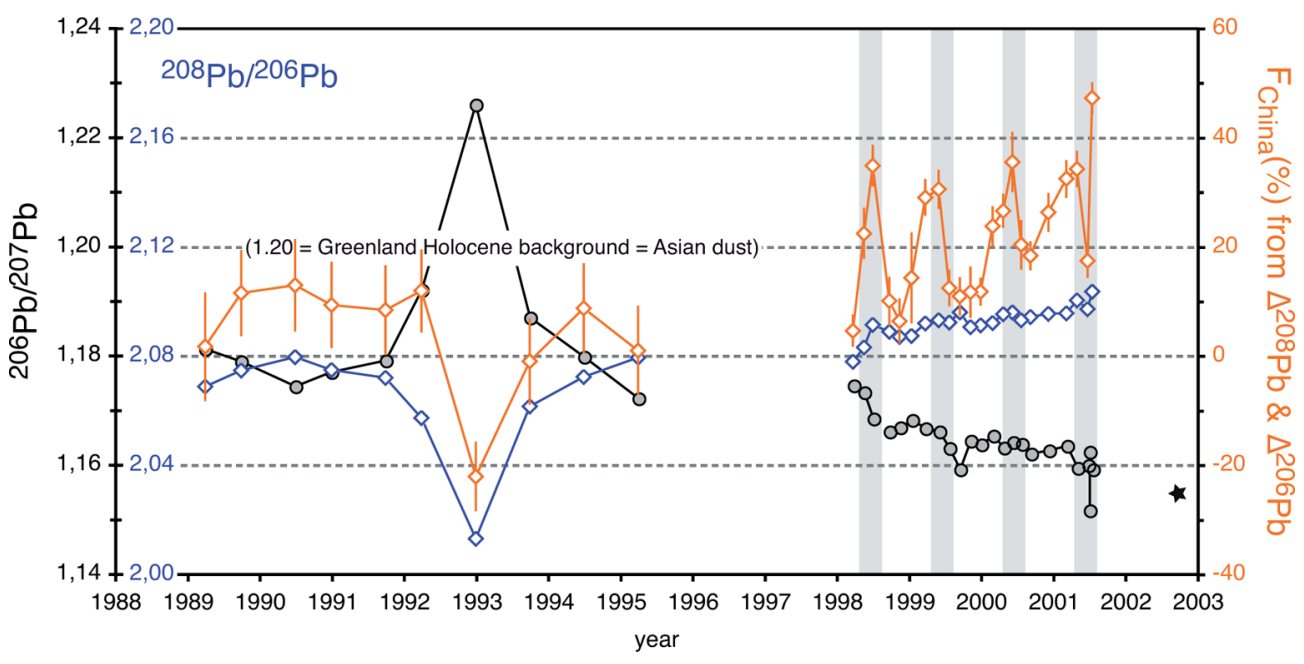

Figure 3. Fraction of the lead isotopic signal attributed to Chinese anthropogenic emissions (based on $\Delta^{208} \mathrm{~Pb}$ and $\Delta^{206} \mathrm{~Pb}$ - see $\mathrm{Section} 3.3-\mathrm{and}$ expressed as $F_{\text {China }}$ in percent; orange diamonds; right axis) together with the ${ }^{208} \mathrm{~Pb} /{ }^{206} \mathrm{~Pb}$ (blue diamonds; inner left axis) and the ${ }^{206} \mathrm{~Pb} /{ }^{207} \mathrm{~Pb}$ ratios (circles; outer left axis) measured in NorthGRIP insoluble particles, as a function of date along the two snow-pit time series; spring seasons over the 1998-2001 times period are highlighted by shaded bars. Typical Chinese urban ${ }^{206} \mathrm{~Pb} /{ }^{207} \mathrm{~Pb}$ value (star symbol) ${ }^{13,42-44,46,47}$ as well as Greenland Holocene (i.e., preindustrial) background ${ }^{206} \mathrm{~Pb} /{ }^{207} \mathrm{~Pb}$ value ${ }^{48}$ reflecting "pure" Asian dust signature, are also shown for reference.

peaks in the spring also (e.g., refs $21,38,39$, and references therein). The seasonal increase in China's relative contribution to the anthropogenic insoluble lead deposited in Greenland actually coincides with large Chinese "natural" dust inputs to central Greenland at that time of the year ${ }^{11,12,20}$ (see SI Figure S3). This temporal correspondence further supports the conclusion that the isotopic shift toward lower ${ }^{206} \mathrm{~Pb} /{ }^{204} \mathrm{~Pb}$ at a given ${ }^{208} \mathrm{~Pb} /{ }^{204} \mathrm{~Pb}$ we are seeing in several NorthGRIP samples really does indicate an increase in the relative influence of Chinese anthropogenic emissions.

Our time-series also suggests that China's relative contribution was rising over the studied period, as best shown by the 1998-2001 time series (Figure 3). This temporal evolution is evident on the ${ }^{208} \mathrm{~Pb} /{ }^{204} \mathrm{~Pb}$ vs ${ }^{206} \mathrm{~Pb} /{ }^{204} \mathrm{~Pb}$ space too (Figure $2 \mathrm{~b})$, where the 1998-2001 samples lie above the 1989-1995 samples as indicated by their respective regression lines. It is interesting to note that the 1989-1995 array is itself shifted in the same direction compared to earlier time series obtained on bulk snow samples from Rosman et al. ${ }^{8}$ covering the 19601988 period. The temporal evolution of the lead isotopic composition in our NorthGRIP snow-pit time series is also illustrated by the ${ }^{208} \mathrm{~Pb} /{ }^{206} \mathrm{~Pb}$ ratio change with time, and by the ${ }^{206} \mathrm{~Pb} /{ }^{207} \mathrm{~Pb}$ ratio record, whose trend is consistent with an increased relative contribution of Chinese anthropogenic aerosols (Figure 3).

In sum, observations based on our snow-pit time series suggest that Chinese aerosols accounted for a substantial and apparently growing fraction of the insoluble anthropogenic lead deposited in central Greenland over the last few decade of the twentieth century. If one can assume that the efficiency of atmospheric transport systems remained unchanged over the study period, the trend we observe implies either growing Chinese inputs or receding emissions in other areas of the Northern hemisphere (such as in the U.S. according to the lead isotopic signal), possibly a combination of the two. Increased Chinese supplies would be in agreement with the fact that Asia-China in particular-has actually become the largest anthropogenic source of trace metals to the atmosphere. ${ }^{34,40}$ However, according to recent estimations based on material consumptions, total atmospheric lead emissions must have decreased significantly in 2001, when China stopped using leaded gasoline. ${ }^{41}$ The fact this is not recorded in our Greenland record-the year 2001 actually shows instead the highest Chinese influence-suggests that insoluble $\mathrm{Pb}$ deposited in Greenland derives mainly from industrial sources of lead (i.e., coal combustion, smelting etc.). Reported $\mathrm{Pb}$ isotopic ratios in the literature for coal combustion products (e.g., ${ }^{206} \mathrm{~Pb} /{ }^{207} \mathrm{~Pb}$ values down to $\left.\sim 1.155\right)^{42-44}$ are consistent with such a hypothesis (see Figure 3 and SI Figure S3). There is also a good agreement between our $\mathrm{Pb}$ isotope record and the estimates of $\mathrm{Pb}$ emissions from coal consumption and ore smelting, which show a slowdown around 1997-1998 before rising again in 1999 and 2000 (see SI Figure S4). In any case, although one should bear in mind that the "excess" $\mathrm{Pb}$ associated with the insoluble fraction may not tell the whole story about all of the lead in the bulk snow, this unique time series gives robust evidence that the impact of China's rising anthropogenic emissions extend well beyond the proximal Pacific region, ${ }^{21,38,45}$ and provides constraints to track Chinese anthropogenic emissions' dispersal. Our work supports indeed the notion that lead isotopic composition $\left(\Delta^{208} \mathrm{~Pb}\right.$ and $\Delta^{206} \mathrm{~Pb}$ in particular) can be used to quantify Chinese contribution to the atmospheric lead pollution. ${ }^{21}$ Considering the sharp increase in Chinese industrial emissions of lead over the past decade (ref 21, and references therein; ref 41) (i.e., since the end of our record), our approach, which can be applied in Greenland again but also in other Northern Hemisphere ice caps, could be of particular interest to monitor the significance of such a rise at the global scale.

\section{ASSOCIATED CONTENT}

Supporting Information

Figures S1-S4 and Table S1. This material is available free of charge via the Internet at http://pubs.acs.org.

\section{AUTHOR INFORMATION}

\section{Corresponding Author}

*E-mail: aloys.bory@univ-lille1.fr. 


\section{Present Address}

${ }^{\perp}$ Université Lille 1, UMR-CNRS Géosystèmes 8217, 59655 Villeneuve d'Ascq cedex, France.

\section{Notes}

The authors declare no competing financial interest.

\section{ACKNOWLEDGMENTS}

This work was supported by the National Science Foundation under (grant OPP96-16146), with additional funds from the University of California Ernest Orlando Lawrence Berkeley National Laboratory (DOE contract DE-AC03-76SF00098), from the Vetlesen Foundation, and from the National Oceanographic and Atmospheric Administration by cooperative agreement (grant NA77RJ0453 UCSIO PO 10156283). This manuscript benefited from comments by two anonymous reviewers. This is LDEO contribution 7745 .

\section{REFERENCES}

(1) Fuhrer, K.; Wolff, E. W.; Johnsen, S. J. Timescales for dust variability in the Greenland Ice Core Project (GRIP) ice core in the last 100,000 years. J. Geophys. Res.: Atmos. 1999, 104 (D24), 3104331052.

(2) Zielinski, G. A.; Mayewski, P. A.; Meeker, L. D.; Whitlow, S.; Twickler, M. S.; Morrison, M.; Meese, D. A.; Gow, A. J.; Alley, R. B. Record of volcanism since 7000 B.C. from the GISP2 Greenland ice core and implications for the volcano-climate system. Science 1994, 264 (5161), 948-952, DOI: 10.1126/science.264.5161.948.

(3) McConnell, J. R.; Edwards, R. Coal burning leaves toxic heavy metal legacy in the Arctic. Proc. Natl Acad. Sci. USA 2008, 105 (34), 12140-12144, DOI: $10.1073 /$ pnas.0803564105.

(4) Bollhöfer, A.; Rosman, K. J. R. The temporal stability in lead isotopic signatures at selected sites in the Southern and Northern Hemispheres. Geochim. Cosmochim. Acta 2002, 66 (8), 1375-1386.

(5) Vallelonga, P.; Van de Velde, K.; Candelone, J. P.; Morgan, V. I.; Boutron, C. F.; Rosman, K. J. R. The lead pollution history of Law Dome, Antarctica, from isotopic measurements on ice cores: $1500 \mathrm{AD}$ to 1989 AD. Earth Planet. Sci. Lett. 2002, 204 (1-2), 291-306.

(6) Biscaye, P. E.; Grousset, F. E.; Revel, M.; VanderGaast, S.; Zielinski, G. A.; Vaars, A.; Kukla, G. Asian provenance of glacial dust (stage 2) in the Greenland Ice Sheet Project 2 Ice Core, Summit, Greenland. J. Geophys. Res.: Oceans 1997, 102 (C12), 26765-26781.

(7) Hong, S. M.; Candelone, J. P.; Patterson, C. C.; Boutron, C. F. Greenland ice evidence of hemispheric lead pollution 2-millennia ago by Greek and Roman civilizations. Science 1994, 265 (5180), 18411843.

(8) Rosman, K. J. R.; Chisholm, W.; Boutron, C. F.; Candelone, J. P.; Hong, S. Isotopic evidence to account for changes in the concentration of lead in Greenland snow between 1960 and 1988. Geochim. Cosmochim. Acta 1994, 58 (15), 3265-3269.

(9) Drab, E.; Gaudichet, A.; Jaffrezo, J. L.; Colin, J. L. Mineral particles content in recent snow at Summit (Greenland). Atmos. Environ. 2002, 36 (34), 5365-5376, DOI: 10.1016/s1352-2310(02) 00470-3.

(10) Zdanowicz, C.; Hall, G.; Vaive, J.; Amelin, Y.; Percival, J.; Girard, I.; Biscaye, P.; Bory, A. Asian dustfall in the St. Elias Mountains, Yukon, Canada. Geochim. Cosmochim. Acta 2006, 70 (14), 3493-3507.

(11) Bory, A. J.-M.; Biscaye, P. E.; Grousset, F. E. Two distinct seasonal Asian source regions for mineral dust deposited in Greenland (NorthGRIP). Geophys. Res. Lett. 2003, 30 (4), 1167 DOI: 10.1029/ 2002 GL016446.

(12) Bory, A. J.-M.; Biscaye, P. E.; Svensson, A.; Grousset, F. E. Seasonal variability in the origin of recent atmospheric mineral dust at NorthGRIP, Greenland. Earth Planet. Sc. Lett. 2002, 196 (3-4), 123134.
(13) Bollhöfer, A.; Rosman, K. J. R. Isotopic source signatures for atmospheric lead: The Northern Hemisphere. Geochim. Cosmochim. Acta 2001, 65 (11), 1727-1740.

(14) Galer, S. J. G. Optimal double and triple spiking for high precision lead isotopic measurement. Chem. Geol. 1999, 157 (3-4), 255-274.

(15) Bales, R. C.; McConnell, J. R.; Mosley-Thompson, E.; Lamorey, G. Accumulation map for the Greenland ice sheet: 1971-1990. Geophys. Res. Lett. 2001, 28 (15), 2967-2970.

(16) Banta, J. R.; McConnell, J. R.; Edwards, R.; Engelbrecht, J. P. Delineation of carbonate dust, aluminous dust, and sea salt deposition in a Greenland glaciochemical array using positive matrix factorization. Geochem. Geophys. Geosyst. 2008, 9 (7), Q07013 DOI: 10.1029/ 2007GC001908.

(17) Fischer, H.; Wagenbach, D.; Kipfstuhl, J. Sulfate and nitrate firn concentrations on the Geenland ice sheet, 1. Large-scale geographical deposition changes. J. Geophys. Res. 1998, 103 (D17), 21,927-21,934.

(18) Svensson, A. Characterization of continental dust in the Greenland GRIP ice core back to $44 \mathrm{kyr}$ BP. Ph.D. dissertation, University of Copenhagen, Copenhagen, Denmark, 1998.

(19) Hegg, D. A.; Warren, S. G.; Grenfell, T. C.; Doherty, S. J.; Clarke, A. D. Sources of light-absorbing aerosol in arctic snow and their seasonal variation. Atmos. Chem. Phys. 2010, 10 (22), 1092310938, DOI: 10.5194/acp-10-10923-2010.

(20) Bory, A. J.-M.; Biscaye, P. E.; Piotrowski, A. M.; Steffensen, J. P. Regional variability of ice core dust composition and provenance in Greenland. Geochem. Geophy. Geosyst. 2003, 4 (12), 1107 DOI: $10.1029 / 2003$ GC000627.

(21) Ewing, S. A.; Christensen, J. N.; Brown, S. T.; Vancuren, R. A.; Cliff, S. S.; Depaolo, D. J. Pb Isotopes as an Indicator of the Asian contribution to particulate air pollution in urban California. Environ. Sci. Technol. 2010, 44 (23), 8911-8916, DOI: 10.1021/es101450t.

(22) VanCuren, R. A.; Cahill, T.; Burkhart, J.; Barnes, D.; Zhao, Y. J.; Perry, K.; Cliff, S.; McConnell, J. Aerosols and their sources at Summit Greenland - First results of continuous size- and time-resolved sampling. Atmos. Environ. 2012, 52, 82-97, DOI: 10.1016/j.atmosenv.2011.10.047.

(23) Shotyk, W.; Zheng, J. C.; Krachler, M.; Zdanowicz, C.; Koerner, R.; Fisher, D., Predominance of industrial $\mathrm{Pb}$ in recent snow (19942004) and ice (1842-1996) from Devon Island, Arctic Canada. Geophys. Res. Lett. 2005, 32 (L21814); doi:10.1029/2005GL023860.

(24) Matsumoto, A.; Hinkley, T. K. Trace metal suites in Antarctic pre-industrial ice are consistent with emissions from quiescent degassing of volcanoes worldwide. Earth Planet. Sci. Lett. 2001, 186 (1), 33-43, DOI: 10.1016/s0012-821x(01)00228-x.

(25) Mortensen, A. K.; Bigler, M.; Gronvold, K.; Steffensen, J. P.; Johnsen, S. J. Volcanic ash layers from the Last Glacial Termination in the NGRIP ice core. J. Quat. Sci. 2005, 20 (3), 209-219, DOI: $10.1002 /$ jqs. 908 .

(26) Sun, S. S. Lead isotopic study of young volcanic-rocks from midocean ridges, ocean islands and island arcs. Philos. Trans. R. Soc., A 1980, 297 (1431), 409-445, DOI: 10.1098/rsta.1980.0224.

(27) Desboeufs, K. V.; Sofikitis, A.; Losno, R.; Colin, J. L.; Ausset, P. Dissolution and solubility of trace metals from natural and anthropogenic aerosol particulate matter. Chemosphere 2005, 58 (2), 195-203, DOI: 10.1016/j.chemosphere.2004.02.025.

(28) Smith, D. B.; Zielinski, R. A.; Rose, W. I.; Huebert, B. J. Watersoluble material on aerosols collected within volcanic eruption clouds. J. Geophys. Res., C: Oceans Atmos. 1982, 87 (NC7), 4963-4972, DOI: 10.1029/JC087iC07p04963.

(29) Grobety, B.; Giere, R.; Dietze, V.; Stille, O. Airborne particles in the urban environment. Elements 2010, 6 (4), 229-234, DOI: $10.2113 /$ gselements.6.4.229.

(30) Simonetti, A.; Gariepy, C.; Banic, C. M.; Tanabe, R.; Wong, H. $\mathrm{K} . \mathrm{Pb}$ isotopic investigation of aircraft-sampled emissions from the Horne smelter (Rouyn, Quebec): Implications for atmospheric pollution in northeastern North America. Geochim. Cosmochim. Acta 2004, 68 (16), 3285-3294, DOI: 10.1016/j.gca.2004.02.008. 
(31) Stecher, O.; Carlson, R. W.; Gunnarsson, B. Torfajokull: A radiogenic end-member of the Iceland $\mathrm{Pb}$-isotopic array. Earth Planet. Sci. Lett. 1999, 165 (1), 117-127.

(32) McCormick, M. P.; Thomason, L. W.; Trepte, C. R. Atmospheric effects of the Mt-Pinatubo eruption. Nature 1995, 373 (6513), 399-404, DOI: 10.1038/373399a0.

(33) Gabrielli, P.; Barbante, C.; Plane, J. M. C.; Boutron, C. F.; Jaffrezo, J. L.; Mather, T. A.; Stenni, B.; Gaspari, V.; Cozzi, G.; Ferrari, C.; Cescon, P. Siderophile metal fallout to Greenland from the 1991 winter eruption of Hekla (Iceland) and during the global atmospheric perturbation of Pinatubo. Chem. Geol. 2008, 255 (1-2), 78-86, DOI: 10.1016/j.chemgeo.2008.06.012.

(34) Pacyna, J. M.; Pacyna, E. G. An assessment of global and regional emissions of trace metals to the atmosphere from anthropogenic sources worldwide. Environ. Rev. 2001, 9, 269-298.

(35) Hegg, D. A.; Warren, S. G.; Grenfell, T. C.; Doherty, S. J.; Larson, T. V.; Clarke, A. D. Source attribution of black carbon in Arctic snow. Environ. Sci. Technol. 2009, 43 (11), 4016-4021, DOI: $10.1021 /$ es803623f.

(36) Mahowald, N.; Albani, S.; Engelstaedter, S.; Winckler, G.; Goman, M. Model insight into glacial-interglacial paleodust records. Quat. Sci. Rev. 2011, 30, 832-854, DOI: 10.1016/j.quascirev.2010.09.007.

(37) Ohara, T.; Akimoto, H.; Kurokawa, J.; Horii, N.; Yamaji, K.; Yan, X.; Hayasaka, T. An Asian emission inventory of anthropogenic emission sources for the period 1980-2020. Atmos. Chem. Phys. 2007, 7 (16), 4419-4444.

(38) Jaffe, D.; McKendry, I.; Anderson, T.; Price, H. Six 'new' episodes of trans-Pacific transport of air pollutants. Atmos. Environ. 2003, 37 (3), 391-404.

(39) VanCuren, R. A.; Cahill, T. Asian aerosols in North America: Frequency and concentration of fine dust. J. Geophys. Res. 2002, 107 (D24), 4804 DOI: 10.1029/2002JD002204.

(40) Bond, T. C.; Bhardwaj, E.; Dong, R.; Jogani, R.; Jung, S. K.; Roden, C.; Streets, D. G.; Trautmann, N. M. Historical emissions of black and organic carbon aerosol from energy-related combustion, 1850-2000. Global Biogeochem. Cycles 2007, 21 (2), 16 DOI: $10.1029 / 2006 \mathrm{gb} 002840$.

(41) Li, Q.; Cheng, H.; Zhou, T.; Lin, C.; Guo, S. The estimated atmospheric lead emissions in China, 1990-2009. Atmos. Environ. 2012, 60, 1-8, DOI: 10.1016/j.atmosenv.2012.06.025.

(42) Diaz-Somoano, M.; Kylander, M. E.; Lopez-Anton, M. A.; Suarez-Ruiz, I.; Martinez-Tarazona, M. R; Ferrat, M.; Kober, B.; Weiss, D. J. Stable lead isotope compositions in selected coals from around the world and implications for present day aerosol source tracing. Environ. Sci. Technol. 2009, 43 (4), 1078-1085, DOI: $10.1021 /$ es801818r.

(43) Tan, M. G.; Zhang, G. L.; Li, X. L.; Zhang, Y. X.; Yue, W. S.; Chen, J. M.; Wang, Y. S.; Li, A. G.; Li, Y.; Zhang, Y. M.; Shan, Z. C. Comprehensive study of lead pollution in Shanghai by multiple techniques. Anal. Chem. 2006, 78 (23), 8044-8050, DOI: 10.1021/ ac061365q.

(44) Widory, D.; Liu, X.; Dong, S. Isotopes as tracers of sources of lead and strontium in aerosols (TSP \& $\mathrm{PM}_{2.5}$ ) in Beijing. Atmos. Environ. 2010, 44 (30), 3679-3687, DOI: 10.1016/j.atmosenv.2010.06.036.

(45) Osterberg, E.; Mayewski, P.; Kreutz, K.; Fisher, D.; Handley, M.; Sneed, S.; Zdanowicz, C.; Zheng, J.; Demuth, M.; Waskiewicz, M.; Bourgeois, J. Ice core record of rising lead pollution in the North Pacific atmosphere. Geophys. Res. Lett. 2008, 35 (5), 4 DOI: 10.1029/ $2007 \mathrm{gl} 032680$.

(46) Cheng, H.; Zhang, G.; Jiang, J. X.; Li, X.; Liu, X.; Li, J.; Zhao, Y., Organochlorine pesticides, polybrominated biphenyl ethers and lead isotopes during the spring time at the Waliguan Baseline Observatory, northwest China: Implication for long-range atmospheric transport. Atmos. Environ. 2007, 41, 4734-4747; DOI: 10.1016/j.atmosenv.2007.03.023.

(47) Mukai, H.; Tanaka, A.; Fujii, T.; Zeng, Y. Q.; Hong, Y. T.; Tang, J.; Guo, S.; Xue, H. S.; Sun, Z. L.; Zhou, J. T.; Xue, D. M.; Zhao, J.;
Zhai, G. H.; Gu, J. L.; Zhai, P. Y. Regional characteristics of sulfur and lead isotope ratios in the atmosphere at several Chinese urban sites. Environ. Sci. Technol. 2001, 35 (6), 1064-1071, DOI: 10.1021/ es001399u.

(48) Rosman, K. J. R.; Chisholm, W.; Hong, S. M.; Candelone, J. P.; Boutron, C. F. Lead from Carthaginian and Roman Spanish mines isotopically identified in Greenland ice dated from $600 \mathrm{BC}$ to $300 \mathrm{AD}$. Environ. Sci. Technol. 1997, 31 (12), 3413-3416. 